\title{
PENGARUH MODIFIKASI SCREW MENJADI BELT PADA GANTRY CONVEYOR COAL SHIP UNLOADING TERHADAP FREKUENSI GANGGUAN POWER CONSUMTION DAN MAINTENANCE COST
}

\author{
Tri Hartutuk Ningsih ${ }^{1}$, Anggra Fiveriati ${ }^{2}$, Muhammad Abdul Azis ${ }^{3}$ \\ 1,3 Jurusan Teknik Mesin/S1 Teknik Mesin Universitas Negeri Surabaya \\ 1triningsih@unesa.ac.id \\ 3muhammadazis@mhs.unesa.ac.id \\ ${ }^{2}$ Politeknik Negeri Banyuwangi \\ 2anggrafiveriati@poliwanggi.ac.id
}

\begin{abstract}
Abstrak - Jurnal ini menjelaskan pengaruh modifikasi screw menjadi belt pada gantry conveyor coal ship unloading terhadap frekuensi gangguan, power consumtion dan maintenance cost. Berdasarkan pengamatan, pengambilan dan pengerjaan data maka dihasilkan; frekuensi gangguan gantry conveyor menurun $90 \%$ dari 40 kali menjadi 4 kali, power consumtion dari yang sebelumnya $110 \mathrm{Kw}$ menjadi $20 \mathrm{Kw}$ sehingga menghemat biaya listrik sebesar Rp. 720.343.998-Rp. 130.971.636=Rp. 589.372.362 per tahun. Sedangkan untuk biaya perawatan/maintenance cost juga mengalami penghematan sebesar Rp. 1.441.242.413-Rp. 102.522.429 = Rp. 1.338.719.984 per 2 tahun Sehingga penghematan biaya pemeliharaan per tahunnya adalah Rp. 669.359.992. Sehingga total efisiensi biaya yaitu sebesar Rp. 589.372.362 per tahun + Rp. 669.359.992 = Rp. 1.258.732.354 per tahun.
\end{abstract}

Kata Kunci-Screw; Belt; Gantry Conveyor Coal Ship Unloading; Power Consumtion; Maintenance Cost.

\begin{abstract}
This journal explains the modification screw be gantry conveyor coal ship unloading belt against frequency disorder, power consumtion and maintenance cost. Based on an examination, data collection and the implementation of the project so produced; gantry conveyor frequency disorder decreased $90 \%$ from 40 time to 4 time, power consumtion decreased from $110 \mathrm{Kw}$ to $20 \mathrm{Kw}$ and save on the cost of electricity of Rp. 720.343.998-Rp. 130.971.636=Rp. 589.372.362/year. As for maintenance cost were also able to save as much as Rp. 1.441.242.413-Rp. 102.522.429 = Rp. 1.338.719.984/ two years. So that the cost savings on the maintenance per year is Rp. 669.359.992, It means the total of of cost efficiency is as much as Rp. 589.372.362 per year $+R$. $669.359 .992=R p .1 .258 .732 .354$ per year.
\end{abstract}

Key Words_-Screw; Belt; Gantry Conveyor Coal Ship Unloading; Power Consumtion; Maintenance Cost.

\section{Pendahuluan}

Mesin yang digunakan dalam proses unloading batu bara di PT Semen Indonesia (Persero) Tbk. adalah jenis continuous ship unloading yang memanfaatkan screw conveyor sebagai alat transportnya (Catalog Siwertell).

Ship unloader batu bara ini menggunakan prinsip kerja bidang miring. Screw conveyor yang memiliki alur diputar sehingga material akan bergerak sesuai dengan alur yang dimiliki oleh screw. Screw conveyor tersebut diarahkan sedemikian rupa sehingga dapat memindahkan batu bara dari kapal tongkang ke collector unit. Terdapat dua jenis screw conveyor pada ship unloading batu bara yaitu vertical screw conveyor dan horizontal screw conveyor. Vertical screw conveyor digunakan untuk mengangkat batu bara dari kapal tongkang menuju tranfer box. Horizontal screw conveyor digunakan untuk meneruskan batu bara dari transfer box, yang telah diangkat oleh vertical screw conveyor menuju ke vertical chute, yang kemudian diteruskan gantry conveyor ke outlet. Outlet ini yang berhubungan langsung dengan collector unit. Collector unit ini sebagai tempat sementara batu bara dari mesin ship unloading sebelum dibawa ke coal storage.

\section{A. Pengertian Screw Conveyor}

Screw conveyor banyak digunakan di industri pertanian dan pengolahan untuk mengangkut atau mengangkat material dalam waktu yang lebih singkat (Owen and Cleary, 2009; Zareiforoush et al., 2010). Screw conveyor terdiri atas screw (ulir) yang berputar, celah sebagai pintu masuk dan keluar material, dan peralatan penggerak. Alat penggerak terdiri atas motor dan reducer (penurun kecepatan), coupling dan dudukan (Li and Liu, 2013). Screw conveyor merupakan alat angkut material yang berbentuk butiran kecil, bubuk, dan cairan dalam berbagai bidang industri. Screw conveyor mempunyai poros spiral yang berputar dalam pipa. Screw conveyor mengangkut material dengan memanfaatkan gerakan putaran poros screw. 


\section{B. Pengertian Belt Conveyor}

Belt conveyor merupakan mesin pemindah material sepanjang arah horizontal atau dengan kemiringan tertentu secara kontinu. Belt conveyor secara luas digunakan pada berbagai industri. Sebagai contoh: Penyalur hasil produksi urea curah ke gudang penyimpanan dan sebagainya (Dwi James, 2008).

\section{Sistem Kerja Siwertell Ship Unloader}

Proses kerja dalam mesin ship unloading ini adalah batu bara yang ada di dalam kapal tongkang ditarik masuk oleh inlet feeder, kemudian diangkat menggunakan vertical screw conveyor, yang kemudian diteruskan oleh horizontal screw conveyor dari tranfer box, melalui vertical chute yang masuk ke gantry conveyor sehingga berakhir di outlet dan menuju collector unit. Dalam hal ini PT Semen Indonesia (Persero) Tbk. collector unit adalah belt conveyor yang akan membawa batu bara dari pelabuhan menuju coal storage (manual book siwertell)

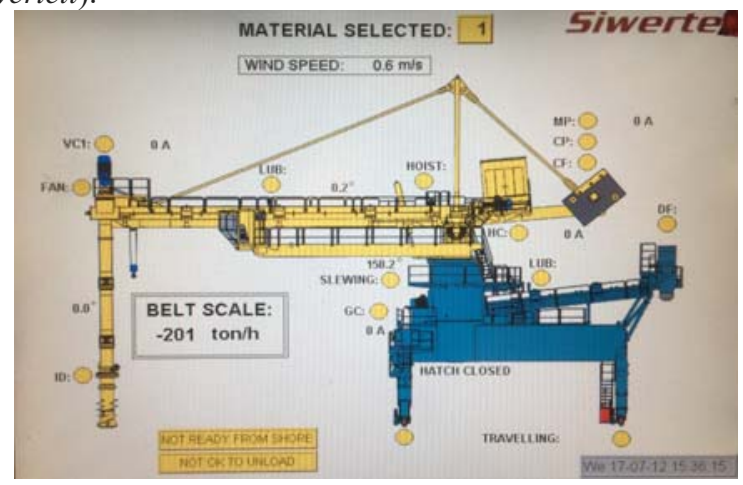

Gbr. 1 Siwertell Ship Unloader

(Sumber : Seksi PMPP PT Semen Indonesia (Persero) Tbk.)

Ketika proses unloading vertical conveyor dan inlet feeder dapat digerakkan $\pm 30^{\circ}$ dari bidang vertikal menjauh atau mendekat dari pelabuhan. Dengan waktu bersamaan lengan horizontal dapat dinaikkan $-20^{\circ}$ dan juga diturunkan $20^{\circ}$, dan kedua lengan conveyor tersebut dapat dibengkokkan. Untuk mengeluarkan inlet feeder dan vertical conveyor dari kapal, lengan horizontal dapat ditinggikan hingga $-25^{\circ}$ dari bidang horizontal.

Secara keseluruhan lengan horizontal dapat bergerak sepanjang pelabuhan pada jalur rel yang ada. Pada perencanaannya lengan horizontal dapat diputar $+110^{\circ}$ atau $110^{\circ}$ dari garis tengah pelabuhan dengan titik pusat pada tower, tapi dapat dibuat tidak terbatas dengan menggunakan limit switches.

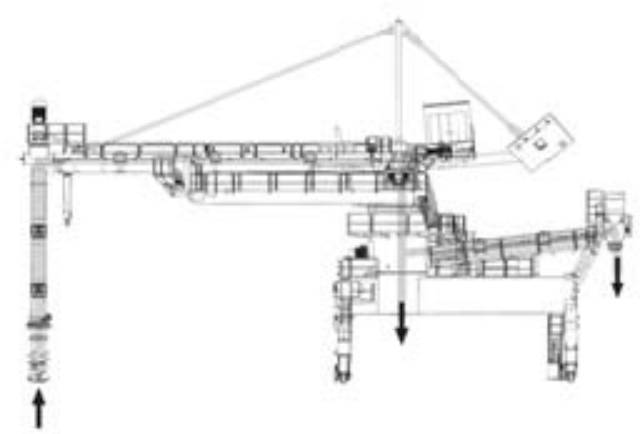

Gbr. 2 Diagram Alur Batu Bara Pada Mesin Ship Unloading

Mesin ship unloading dapat bekerja pada kecepatan angin hingga $20 \mathrm{~m} / \mathrm{sRem}$ yang digunakan sanggup mempertahankan posisi mesin ship unloadeing pada kecepatan angin tersebut. Ketika tidak digunakan mesin sebaiknya diparkirkan dengan kondisi vertical arm diistirahatkan pada storm lock support. Ketika kecepatan angin mencapai $20 \mathrm{~m} / \mathrm{s}$ vertical arm harus diikat pada storm lock support dengan turn biuckle.

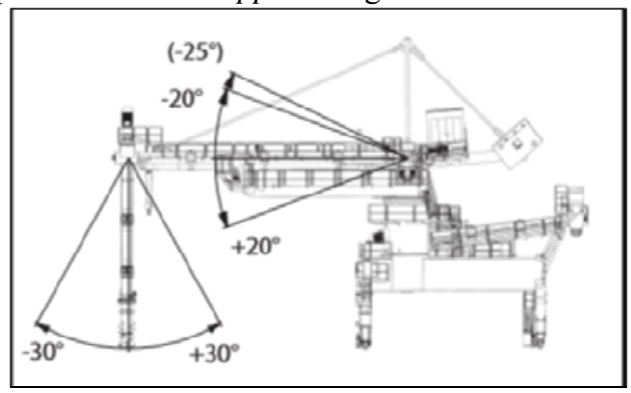

Gbr. 3 Rotasi Mesin Ship Unloading

(Sumber : Seksi PMPP PT Semen Indonesi (Persero) Tbk.)

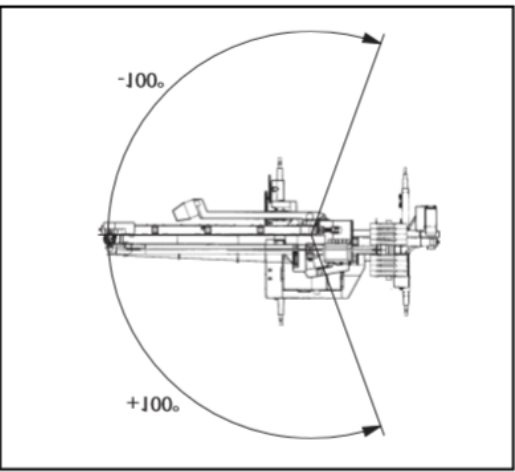

Gbr. 4 Rotasi Arm Horizontal Conveyor

(Sumber : Seksi PMPP PT Semen Indonesia (Persero) Tbk.)

2. Persiapan Umum Sebelum Start Up

Pelumasan dan kontrol preventif sebelum ship unloader. Prosedur pelumasan dimulai dengan mengumpulkan pistol gemuk yang diisi dengan gemuk tipe $\mathrm{E}$ dan dengan kaleng gemuk tipe D (manual book siwertell).

a. Lumasi bantalan bagian bawah, pompa sampai minyak segar muncul dari segel. 
b. Pelumasan cincin roda gigi slewing, rak terbuka. Periksa dan, jika diperlukan, lumasi rak terbuka secukupnya, dengan pelumas tipe D.

c. Periksa tingkat oli dan temperatur oli di tangki oli hidraulik. Periksa juga apakah ada kebocoran oli atau tidak di dalam kabinet hidraulik.

d. Lepaskan rem rel.

Pengendalian:

a. Periksa agar tidak ada personil yang berada di area slewing dari ship unloader.

b. Periksa bagian atau alat yang tertinggal di sistem lengan. Khususnya setelah perawatan dan / atau perbaikan pekerjaan.

c. Periksa juga pompa hidraulic agar tidak dikosongkan.

d. Semua gerakan ship unloader dikendalikan oleh dua joystick di kabin atau pada kotak remote control, dengan meletakkan satu tangan pada setiap tuas kontrol.

\section{Gangguan pada Gantry Conveyor}

Penggunaan screw conveyor untuk Unloading Batu bara juga berpotensi besar untuk menimbulkan berbagai masalah. Masalah yang dihadapi akibat penggunaa screw conveyor diantaranya, screw macet apabila ada material asing yang tercampur di batu bara. Saat musim hujan, material batu bara cenderung lengket sehingga material batu bara mudah menempel didaun screw yang menyebabkan screw macet karena overload. Lifetime yang pendek dari screw karena batu bara termasuk material yang abrasive, apabila daun screw sudah aus, maka mudah terjadi bending pada daun screw tersebut.
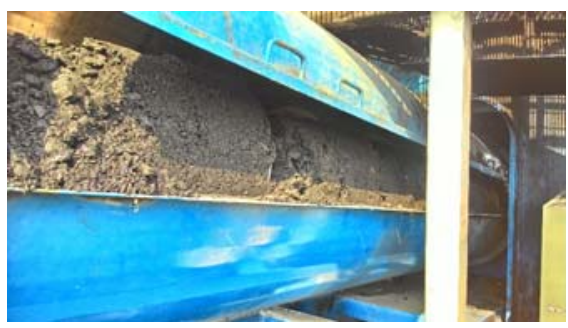

Gbr. 5 Screw Overload

(Sumber : Seksi PMPP PT Semen Indonesia (Persero) Tbk.)

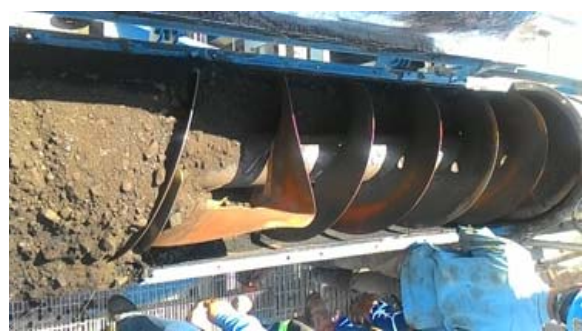

Gbr. 6 Daun Screw Aus/Bending

(Sumber : Seksi PMPP PT Semen Indonesia (Persero) Tbk.)

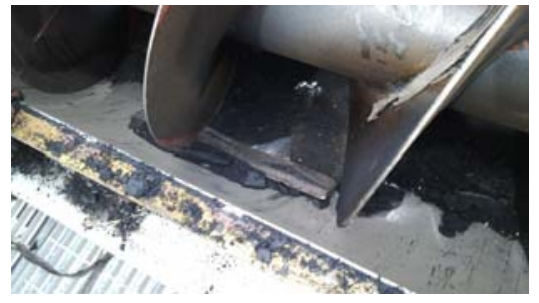

Gbr. 7 Masuknya Material Asing

(Sumber : Seksi PMPP PT Semen Indonesia (Persero) Tbk.)

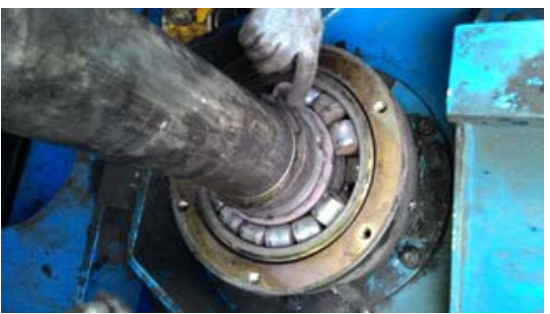

Gbr. 8 Bearing Rusak

(Sumber : Seksi PMPP PT Semen Indonesia (Persero) Tbk.)

\section{METODE}

Melakukan analisa penyebab Masalah pada Gantry Screw Conveyor menggunakan metode analisa sebab akibat

(fishbone diagram) :

a. Faktor manusia (Man)

1) Screw Conveyor Overload

2) Pola Operasi yang tidak sesuai

1.1 Personil Kurang berpengalaman

b. Faktor Alat

1) Screw Conveyor Macet

1.1 Terkena material asing

2) Material Batu bara lengket

2.1 Batu bara basah kena air hujan

3) Screw Conveyor Suara kasar

3.1 Liner casing aus

3.2 Daun screw bending

4) Screw Conveyor Vibrasi tinggi

4.1 Metal Bearing aus

4.2 Screw conveyor missalignment

5) Daun Screw Conveyor bending

5.1 Daun screw aus

5.2 Daun screw menghantam material asing

6) Screw Conveyor putus

6.1 Screw conveyor aus

6.1.1 Material batu bara abrasive tinggi

c. Faktor Metode

1) Material batubata menumpuk di discharge chute

1.1 Schedule pembersihan kurang

d. Faktor Material

1) Screw conveyor dan casing cepat aus

1.1 Material batu bara abrasive dan ukurannya besar

e. Faktor Lingkungan (Environment)

1) Material batu bara lengket

1.1 Musim hujan material basah terkena air hujan

Tri Hartutuk Ningsih: Pengaruh Modifikasi Screw Menjadi... 


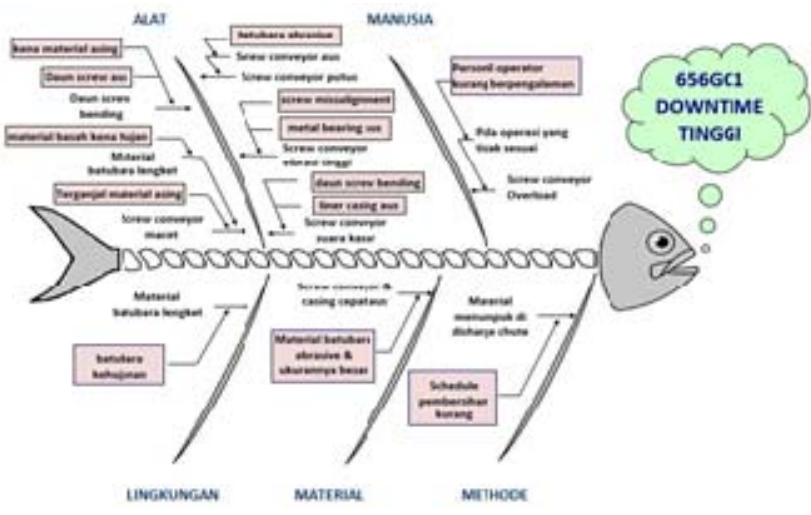

Gbr. 9 Fishbone diagram

(Sumber : Seksi PMPP PT Semen Indonesia (Persero) Tbk.)

f. Menetapkan Penyebab Yang Diduga Dominan

Berdasarkan perhitungan indek NGT sesuai rumus $1 / 2 n+1$, maka didapatkan calon penyebab yang diduga dominan dan akan diuji dilangkah ketiga, sebagai berikut :

a. Material Asing

b. Daun screw aus

c. Screw conveyor misalignment

d. Mateial batu bara lengkat karena basah

e. Linner casing aus

\section{HASIL DAN DISKUSI}

Menguji dan Menentukan Penyebab Dominan Menguji Korelasi

\begin{tabular}{|c|c|}
\hline$X$ & $Y$ \\
\hline 1 & 2 \\
\hline 2 & 4 \\
\hline 4 & 6 \\
\hline 5 & 8 \\
\hline 6 & 10 \\
\hline 8 & 12 \\
\hline 9 & 14 \\
\hline
\end{tabular}

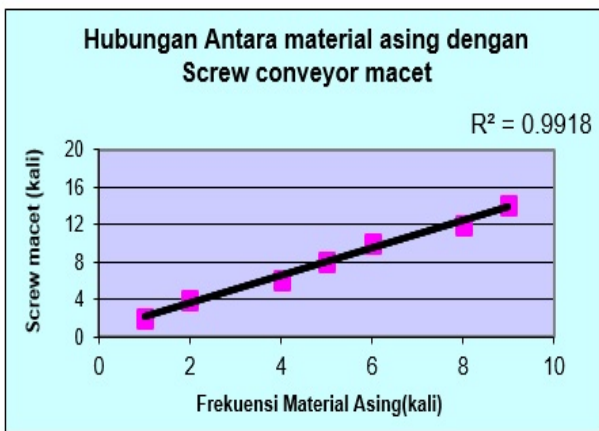

Gbr. 10 Hubungan Antara Frekuensi Material Asing Dengan Screw Conveyor Macet

(Sumber : Seksi PMPP PT Semen Indonesia (Persero) Tbk.)

\section{Keterangan :}

Data berikut merupakan data yang diperoleh berdasarkan frekuensi material asing yang menyebabkan screw macet.

Sumbu $(X)=$ Frekuensi material asing

Sumbu $(Y)=$ Screw macet

Kesimpulan :

Terdapat korelasi positif kuat, $\mathrm{R}=0.99$

\begin{tabular}{|c|c|}
\hline$X$ & $Y$ \\
\hline 1 & 4 \\
\hline 2 & 8 \\
\hline 3 & 10 \\
\hline 4 & 12 \\
\hline 5 & 14 \\
\hline 6 & 16 \\
\hline 7 & 22 \\
\hline
\end{tabular}

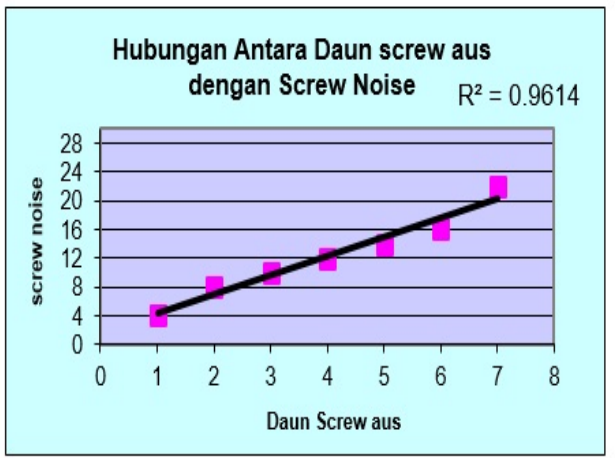

Gbr. 11 Hubungan Antara Daun Screw Aus Dengan Noise Tinggi.

(Sumber : Seksi PMPP PT Semen Indonesia (Persero) Tbk.)

Keterangan :

Data berikut merupakan data yang diperoleh berdasarkan daun screw aus yang menyebabkan screw mengalami noise tinggi.

Sumbu $(\mathrm{X})=$ Daun screw aus

Sumbu $(\mathrm{Y})=$ Screw noise

Kesimpulan :

Terdapat korelasi positif kuat, $\mathrm{R}=0.96$

\begin{tabular}{|c|c|}
\hline$X$ & $Y$ \\
\hline 1 & 1 \\
\hline 2 & 2 \\
\hline 3 & 4 \\
\hline 4 & 5 \\
\hline 5 & 6 \\
\hline 6 & 7 \\
\hline 7 & 9 \\
\hline
\end{tabular}

Hubungan Antara material lengket dengan Screw conveyor overload

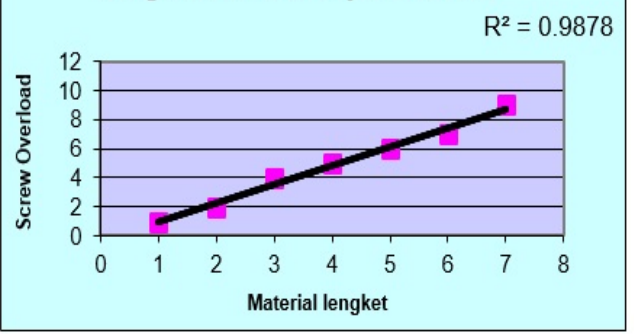

Gbr. 12 Hubungan Antara Missalignment Screw Dengan Vibrasi Tinggi (Sumber : Seksi PMPP PT Semen Indonesia (Persero) Tbk.)

Keterangan :

Data berikut merupakan data yang diperoleh berdasarkan kondisi material lengket yang menyebabkan overload pada screw conveyor.

Sumbu $(\mathrm{X})=$ Material lengket

Sumbu (Y) = Screw overload

Kesimpulan :

Terdapat korelasi positif kuat, $\mathrm{R}=0.98$

\begin{tabular}{|l|l|}
\hline$X$ & $Y$ \\
\hline 1 & 1 \\
\hline 2 & 2 \\
\hline 3 & 4 \\
\hline 4 & 5 \\
\hline 5 & 6 \\
\hline 6 & 7 \\
\hline 7 & 9 \\
\hline
\end{tabular}

Hubungan Antara material lengket dengan Screw conveyor overload

$R^{2}=0.9878$

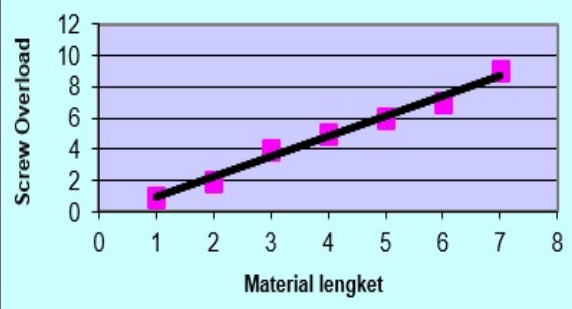

Gbr. 13 Hubungan Antara Material Lengket Dengan Screw Conveyor Overload

(Sumber : Seksi PMPP PT Semen Indonesia (Persero) Tbk.) 
Keterangan :

Data berikut merupakan data yang diperoleh berdasarkan kondisi material lengket yang menyebabkan overload pada screw conveyor.

Sumbu $(\mathrm{X})=$ Material lengket

Sumbu (Y) = Screw overload

Kesimpulan :

Terdapat korelasi positif kuat, $\mathrm{R}=0.98$

\begin{tabular}{|c|c|}
\hline$X$ & $Y$ \\
\hline 1 & 3 \\
\hline 2 & 6 \\
\hline 3 & 7 \\
\hline 4 & 9 \\
\hline 5 & 11 \\
\hline 6 & 13 \\
\hline 7 & 18 \\
\hline
\end{tabular}

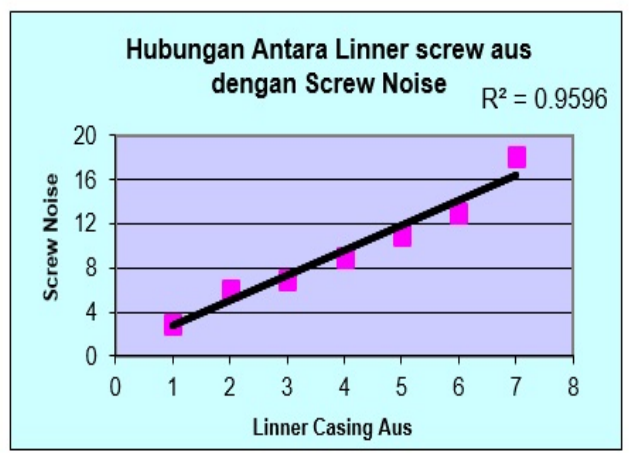

Gbr. 14 hubungan antara Linner casing aus dengan Screw Noise (Sumber : Seksi PMPP PT Semen Indonesia (Persero) Tbk.)

\section{Keterangan :}

Data berikut merupakan data yang diperoleh berdasarkan kondisi linner casing yang aus menyebabkan screw noise.

Sumbu $(\mathrm{X})=$ Screw noise

Sumbu $(\mathrm{Y})=$ Liner casing aus

Kesimpulan :

Terdapat korelasi positif kuat, $\mathrm{R}=0.959$

5.1 Menentukan Penyebab Dominan

TABEL I

DATA SHEET PENYEBAB DOMINAN

\begin{tabular}{|c|c|c|c|c|}
\hline No & $\begin{array}{c}\text { Faktor } \\
\text { Penyebab }\end{array}$ & $\mathbf{r}$ & $\%$ & $\cdot$ \\
\hline 1 & $\begin{array}{l}\text { Adanya material } \\
\text { asing }\end{array}$ & 0.9918 & 20.363 & 73.307 \\
\hline 2 & $\begin{array}{l}\text { Kondisi material } \\
\text { yang lengket }\end{array}$ & 0.9878 & 20.281 & 73.011 \\
\hline 3 & $\begin{array}{l}\text { Screw } \\
\text { Convenyor } \\
\text { Missalignment }\end{array}$ & 0.9700 & 19.915 & 71.695 \\
\hline 4 & Daun Screw Aus & 0.9614 & 19.739 & 71.695 \\
\hline \multirow[t]{2}{*}{5} & $\begin{array}{l}\text { Linner Casing } \\
\text { Aus }\end{array}$ & 0.9596 & 19.702 & 71.927 \\
\hline & & 4.8706 & 100 & 360 \\
\hline
\end{tabular}

Diagram pie

Hubungan Antar Penyebab

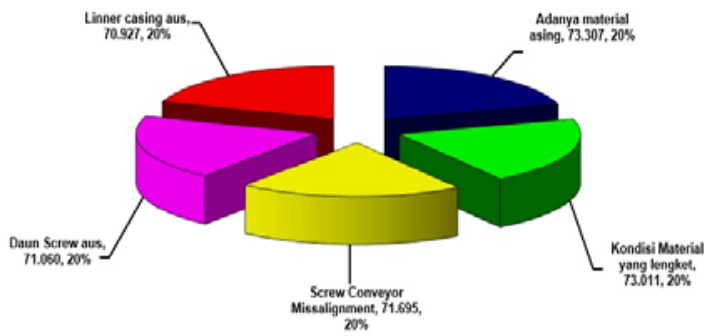

Gbr. 15 Hubungan Antar Penyebab Dominan

(Sumber : Seksi PMPP PT Semen Indonesia (Persero ) Tbk. )
Berdasarkan hasil pengujian terhadap 5 faktor penyebab diatas, dapat disimpulkan bahwa kelima faktor tersebut memiliki koefisien korelasi $\geq 0.714$ sehingga dapat dimasukkan kedalam faktor penyebab dominan. Untuk itu, kelima faktor penyebab tersebut akan dibawa kelangkah selanjutnya untuk dilakukan perbaikan.

6. Perbandingan Fekuensi Gangguan

TABEL III

FREKUENSI GANGGUAN SEBELUM PERBAIKAN

\begin{tabular}{|c|l|c|c|c|}
\hline No & Problem & $\begin{array}{c}\text { Frekuensi } \\
\text { (Kali) }\end{array}$ & $\mathbf{\%}$ & $\begin{array}{c}\text { Kum } \\
(\mathbf{\%})\end{array}$ \\
\hline 1 & Screw Macet & 8 & 20.00 & 20.00 \\
\hline 2 & $\begin{array}{l}\text { Screw } \\
\text { Overload }\end{array}$ & 6 & 15.00 & 35.00 \\
\hline 3 & $\begin{array}{l}\text { Casing } \\
\text { Aus/Bocor }\end{array}$ & 12 & 30.00 & 65.00 \\
\hline 4 & $\begin{array}{l}\text { Daun Screw } \\
\text { Aus/Bending }\end{array}$ & 6 & 15.00 & 80.00 \\
\hline 5 & $\begin{array}{l}\text { Metal } \\
\text { Bearing Aus }\end{array}$ & 8 & 20.00 & 100 \\
\hline & Jumlah & 40 & 100.00 & \\
\hline
\end{tabular}

TABEL IIIII

FREKUENSI GANGGUAN SETELAH PERBAIKAN

\begin{tabular}{|l|l|c|c|l|}
\hline No & Equipment & $\begin{array}{l}\text { Frekuensi } \\
\text { (Kali) }\end{array}$ & $\mathbf{\%}$ & $\begin{array}{l}\text { Kum } \\
(\%)\end{array}$ \\
\hline 1 & $\begin{array}{l}\text { Belt Conv. } \\
\text { Misstracking }\end{array}$ & 3 & 75.00 & 75.00 \\
\hline 2 & $\begin{array}{l}\text { Rubber Skirt } \\
\text { Aus }\end{array}$ & 1 & 25.00 & 100.00 \\
\hline 3 & $\begin{array}{l}\text { Carring Roll } \\
\text { Rusak }\end{array}$ & 0 & 00.00 & 100.00 \\
\hline 4 & Scapper Aus & 0 & 00.00 & 100.00 \\
\hline 5 & $\begin{array}{l}\text { Conveyor } \\
\text { Over Load }\end{array}$ & 0 & 00.00 & 100.00 \\
\hline & Jumlah & 4 & 100.00 & \\
\hline
\end{tabular}

Jadi dari data tabel diatas dapat disimpulkan bahwa frekuensi gangguan pada gantry conveyor menurun setelah dilakukan modifikasi. Gangguan sebelum modifikasi sebanyak 40 kali dan gangguan setelah modifikasi sebanyak 4 kali. 
7. Perhitungan Power Consumtion

\begin{tabular}{|c|c|}
\hline \multicolumn{2}{|c|}{ 4.2 VERTICAL CONTEYOR } \\
\hline TYPE & Serew conveyor; VST 640 OD \\
\hline SCREW DAAMETER & $640 \mathrm{~mm}$ \\
\hline LENGTH & $13,25 \mathrm{~m}$ \\
\hline TRANSMIZSION & Enclosed oil lubricated Gear \\
\hline MOTOR TYPE / SIZE & $\mathrm{AC}$ motor / 355kW \\
\hline CONTROL SYSTEM & Direct start, reversible \\
\hline \multicolumn{2}{|c|}{ 4.3 HORIZONTAL CONVEYOR } \\
\hline TYPE & Screw conveyor; HST 700 \\
\hline SCREW DIAMETER & $700 \mathrm{~mm}$ \\
\hline LENGTH & $20,0 \mathrm{x}$ \\
\hline TRANSMUSSIUN & Encloued oil lubricated Gear \\
\hline MOTOR TYPE / SIZE & $\mathrm{AC}$ motor / $200 \mathrm{~kW}$ \\
\hline CONTROL SYSTEM & Direct start \\
\hline OTHER & Speed guard \\
\hline \multicolumn{2}{|c|}{ 4.4 GANTRY CONVTYOR } \\
\hline TYPE & Serew conveyor, HST 700 \\
\hline SCREW DIAMETER & $700 \mathrm{~mm}$ \\
\hline LENGTH & $12 \mathrm{~m}$ \\
\hline TRANSMISSION & Enclosed oil lubricatod hollow shat Gear \\
\hline MOTOR TVTE / SLEL & AC motor $/ 110 \mathrm{~kW}$ \\
\hline CONTROI SYSTEM & Direct start \\
\hline OTHER & Speed gaard \\
\hline
\end{tabular}

Gbr. 16 Spesifikasi Ship Unloading

(Sumber : Seksi PMPP PT Semen Indonesia (Persero) Tbk.)

Dari data diatas, bahwa screw conveyor pada gantry conveyor memerlukan daya motor sebesar $110 \mathrm{Kw}$ untuk dapat beroperasi. Dengan demikian, biaya power consumtion dari motor listrik sebagai berikut :

$$
\begin{aligned}
\text { Diketahui : Daya motor }= & 110 \mathrm{~kW} \\
\text { Tarif dasar industry } & \mathrm{Rp} .996,74 / \mathrm{kWh} \\
\text { Running hour } / \text { Thn } & 6570 \mathrm{~h} \\
\text { Biaya power consumtion }= & 110 \mathrm{KW} \times \mathrm{Rp} .996,74 / \mathrm{kWh} \times \\
& 6570 \mathrm{~h} \\
= & \text { Rp. } 720.343 .998
\end{aligned}
$$

\begin{tabular}{|c|c|c|c|c|}
\hline \multicolumn{5}{|c|}{ SPECIFICATION DATA SHEET } \\
\hline $\begin{array}{l}\text { PROJECT NAME } \\
\text { NO. WBS }\end{array}$ & \multicolumn{4}{|l|}{ BELT CONVEYOR GANTRY SIWERTEL } \\
\hline Equipment & \multirow{4}{*}{\multicolumn{4}{|c|}{$\begin{array}{l}\text { BELT CONVEYOR } \\
\text { BELT CONVEYOR GANTRY SIWERTEL }\end{array}$}} \\
\hline Equip. No & & & & \\
\hline Project Name & & & & \\
\hline \multirow[t]{2}{*}{ Departement } & & Tanggal : 02-Sep-16 & \\
\hline & & & Rev: & 0 \\
\hline ITEM & DETAILS/ DESCRIPTION & UNIT & DATA & REMARK \\
\hline \multirow[t]{5}{*}{ General } & Capacity : design & $t / h$ & 770 - & \\
\hline & Conveyor speed & $\mathrm{m} / \mathrm{s}$ & 2.5 & \\
\hline & Dfiver power req'd (max) & $\mathrm{kW}$ & 18.5 & \\
\hline & Center distance & $\mathrm{mm}$ & 13919 & \\
\hline & Inclination & $\circ$ & 7 & \\
\hline \multirow[t]{5}{*}{ Material Conveyed } & Description & & Coal & \\
\hline & Grain Size (max.) & $\mathrm{mm}$ & 25 & \\
\hline & Temperature & ${ }^{\circ} \mathrm{C}$ & AMB & \\
\hline & Moisture & $\%$ & Mil & \\
\hline & Bulk Density & $t / \mathrm{m}^{3}$ & 0.8 & \\
\hline \multirow[t]{5}{*}{ Beit } & Width & $\mathrm{mm}$ & 1200 & \\
\hline & Contruction & - & EP $315 \times 3$ & \\
\hline & Covers : top/ bottom & $\mathrm{mm}$ & $6 \longdiv { 2 }$ & \\
\hline & Max. Tension & $\mathrm{kg} / \mathrm{cm}$ & 945 & \\
\hline & Temperature rating of cover & ${ }^{\circ} \mathrm{C}$ & $A M B$ & \\
\hline \multirow[t]{6}{*}{ Pulleys } & Pulley dia - drive & $\mathrm{mm}$ & 6000 & \\
\hline & Rubber lagging - thickness (drive) & $\mathrm{mm}$ & \pm 12.5 & \\
\hline & Pulley dia - tail & $\mathrm{mm}$ & 500 & \\
\hline & Pulley dia - bend & $\mathrm{mm}$ & - & \\
\hline & Pulley dia - take-up & $\mathrm{mm}$ & - & \\
\hline & Pulley dia - snub & $\mathrm{mm}$ & 300 & \\
\hline \multirow[t]{3}{*}{ Carrying idlers } & Manufacture & & $=$ & \\
\hline & Rolis : Diameter/ Trough Angle & $\mathrm{mm} / \mathrm{s}$ & $140 / 35^{\circ}$ & \\
\hline & Ioler spacing : normal//training & $\mathrm{mm}$ & $1000 / 20000$ & \\
\hline \multirow[t]{2}{*}{ Return idlers } & Manufacture &. & - & \\
\hline & Ieler spacing : normal! training & $\mathrm{mm}$ & $3000 / 30000$ & \\
\hline \multirow[t]{3}{*}{ Gearbox } & Type & . & Heary Duty & \\
\hline & Ratio & . & 18.59 & \\
\hline & Make/model no. & & Bevel Helical. & \\
\hline High speed coupling & Type & . & Grid & \\
\hline Low speed coupling & Type &. & Grid & \\
\hline \multirow[t]{2}{*}{ V-belt drive } & Quantity/ belt profile & - & N/A & \\
\hline & Sheaves : Drive/ Driven O.D. & 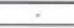 & $\mathrm{N} / \mathrm{A}$ & \\
\hline Backstop & Model & - & Internal & \\
\hline \multirow[t]{2}{*}{ Motor } & Power/ Speed & $\mathrm{kW} / \mathrm{RPM}$ & $18.5 / \pm 1480$ & \\
\hline & & $\mathrm{V} / \mathrm{PH} / \mathrm{Hz}$ & $380 / 3 / 50$. & \\
\hline
\end{tabular}

Maka biaya power consumtion sebelum modifikasi adalah : Rp. 720.343.998
Gbr. 17 Specification Data Sheet

(Sumber : Seksi PMPP PT Semen Indonesi (Persero) Tbk.)

Dari data spesifikasi di atas, bahwa belt conveyor pada gantry conveyor memerlukan daya motor sebesar $18,5 \mathrm{Kw}$ atau dibulatkan menjadi $20 \mathrm{Kw}$ untuk dapat beroperasi. Dengan demikian, biaya power consumtion dari motor listrik sebagai berikut :

Diketahui : Daya motor $=18,5 \mathrm{~kW} \sim 20 \mathrm{~kW}$

Tarif dasar industri $\quad=$ Rp. 996,74/kWh

Running hour / Thn $\quad=6570 \mathrm{~h}$

Biaya power consumtion $=20 \mathrm{Kw} \times \mathrm{Rp} .996,74 / \mathrm{kWh} \times 6570 \mathrm{~h}$

$$
=\text { Rp. } 130.971 .636
$$

Maka biaya power consumtion sesudah modifikasi adalah Rp. 130.971.636

Jadi hasil perbaikan yang telah dilakukan dapat menghemat konsumsi energi listrik sebesar: Rp. 720.343.998-Rp. $130.971 .636=$ Rp. 589.372 .362 per tahun.

8. Perhitungan Maintenance Cost

Untuk mengetahui biaya perbandingan biaya pemeliharaan gantry conveyor sebelum dan sesudah modifikasi adalah sebagai berikut : 
TABEL IVV

MAINTENANCE COST SCREW CONVEYOR

\begin{tabular}{|c|c|c|c|c|c|}
\hline No & Part List & QTY & SAT & $\begin{array}{l}\text { Price } \\
(\mathrm{Rp})\end{array}$ & $\begin{array}{l}\text { Total } \\
\text { (Rp) }\end{array}$ \\
\hline 1 & $\begin{array}{l}\text { Screw } \\
\text { Transport } \\
\text { Gantry } \\
\text { Conveyor } \\
\text { Inlet Art } \\
\text { No.8008684 }\end{array}$ & 1 & EA & $435,604,000$ & $435,604,000$ \\
\hline 2 & $\begin{array}{l}\text { Screw } \\
\text { Transport } \\
\text { Gantry } \\
\text { Conveyor } \\
\text { Art } \\
\text { No.8008687 }\end{array}$ & 1 & EA & $400,255,000$ & $400,255,000$ \\
\hline 3 & $\begin{array}{l}\text { Screw } \\
\text { Transport } \\
\text { Gantry } \\
\text { Conveyor } \\
\text { Outlet Art } \\
\text { No.8008688 }\end{array}$ & 1 & EA & $415,650,000$ & $415,650,000$ \\
\hline 4 & $\begin{array}{l}\text { Bearing } \\
\text { Holder } \\
\text { Complete }\end{array}$ & 2 & EA & $85,000,000$ & $170,000,000$ \\
\hline 5 & $\begin{array}{l}\text { Bearing } \\
\text { Head } 22326\end{array}$ & 1 & EA & $3,761,913$ & $3,761,913$ \\
\hline 6 & $\begin{array}{l}\text { Beraing Tail } \\
1214\end{array}$ & 1 & EA & 291,500 & 291,500 \\
\hline 7 & $\begin{array}{l}\text { Metal } \\
\text { Bearing }\end{array}$ & 4 & EA & $3,920,000$ & $15,680,000$ \\
\hline & & & & & $1,441,242,413$ \\
\hline
\end{tabular}

TABEL VV

MAINTENANCE COST BELT CONVEYOR

\begin{tabular}{|c|l|c|c|c|c|}
\hline $\begin{array}{l}\text { N } \\
\mathbf{0}\end{array}$ & \multicolumn{1}{|c|}{ Part List } & QTY & SAT & \multicolumn{1}{c|}{$\begin{array}{c}\text { Price } \\
(\mathbf{R p})\end{array}$} & $\begin{array}{c}\text { Total } \\
(\mathbf{R p})\end{array}$ \\
\hline 1 & $\begin{array}{l}\text { Belt, Conv, } \\
\text { 1200mmx3 } \\
\text { PLYxEP315x5mm }\end{array}$ & 35 & M & $1,280,000$ & $44,800,000$ \\
\hline 2 & $\begin{array}{l}\text { Carrier Roller } \\
\text { Idler }\end{array}$ & 39 & EA & 358,500 & $13,981,500$ \\
\hline 3 & $\begin{array}{l}\text { Rubber Disc } \\
\text { Return Roller Idler }\end{array}$ & 5 & EA & 979,000 & $4,895,000$ \\
\hline 4 & Belt Cleaner & 1 & EA & $19,434,929$ & $19,434,929$ \\
\hline 5 & Rubber Skirt & 2 & EA & $6,975,000$ & $13,950,000$ \\
\hline 6 & $\begin{array}{l}\text { Transition Roller } \\
\text { Idler 20 Deg }\end{array}$ & 2 & EA & $2,730,500$ & $5,461,000$ \\
\hline & \multicolumn{2}{|l|}{} & & & $\mathbf{1 0 2 , 5 2 2 , 4 2 9}$ \\
\hline
\end{tabular}

\section{KESIMPULAN}

Dari hasil perbandingan biaya maintenance selama 2 tahun diatas, diketahui bahwa biaya maintenance untuk screw conveyor jauh lebih tinggi dari pada maintenance belt Cconveyor. Dari hasil perbaikan ini diperoleh penghematan biaya pemeliharaan sebesar: Rp. 1.441.242.413-Rp. 102.522.429= Rp. 1.338.719.984 per 2 tahun

Maka penghematan biaya maintenance/pemeliharaan per tahunnya adalah : Rp. 669.359.992

Berdasarkan pengamatan, pengambilan dan pengerjaan data maka dapat diambil kesimpulan sebagai berikut:

a. Frekuensi gangguan gantry conveyor menurun $90 \%$ dari 40 kali menjadi 4 kali b. Power consumtion dari yang sebelumnya $110 \mathrm{Kw}$ menjadi $20 \mathrm{Kw}$ sehingga menghemat biaya listrik sebesar Rp. 720.343 .998 - Rp. 130.971.636 = Rp. 589.372.362 per tahun.

c. Maintenance cost juga mengalami penghematan sebesar Rp. 1.441.242.413 - Rp. 102.522.429 = Rp. 1.338.719.984 per 2 tahun Maka penghematan biaya pemeliharaan per tahunnya adalah : Rp. 669.359.992

d. Total efisiensi biaya yaitu sebesar : Rp. 589.372 .362 per tahun + Rp. 669.359.992 = Rp. 1.258.732.354 per tahun.

\section{REFERENSI}

[1] Depari, Prianto. (2009). "Studi Pengaruh Ukuran Butir Dan Tingkat Kelembaban Pasir Terhadap Perfornansi Belt Conveyor Pada Pabrik Pembuatan Tiang Beton". Medan: FT USU.

[2] Erino fiardi. (2012). "Analisa Kerja Belt Conveyor 5857-V Kapasitas 600 Ton Per Jam . Bengkulu : Jurnal Rekayasa Mesin, Hal:451.

[3] James, Dwi. (2008). "Perancangan Sistem Konveyor Kapasitas 1500 TPH Dan Analisa Kekuatan Pin Pada Rantai Reclaim Feeder". Jakarta: FT UI. [4] Metriadi. (2005). "Perawatan Pada Unit Belt Bucket Elevator" Padang: Perpustakaan Semen Padang.

[5] Rahayu, Tri., M. Rahna, dan Teguh Martianto. (2013). "Rekayasa Alat Penyaring Limbah Ciar Model Screw Conveyor". Yogyakarta: Majalah Kulit, Karet dan, Plastik Vol.29, No.2, Desember 2013, hh. 105-110.

[6] Redjeki, Sri. 2016. "Kesehatan dan Keselamatan Kerja". Jakarta: Kementerian Kesehatan Republik Indonesia.

[7] Satriadi. (2010). "Analisa Kecepatan Alir Semen Pada Horizontal Screw Conveyor Dengan Ukuran 315MMx2155MM Di PT Semen Padang. Padang: Fakultas Teknologi Industri Universitas Bung Hatta

[8] Tim Penyusun PI. 2014 Pedoman Praktik Industri Fakultas Teknik. Surabaya 